\title{
DECOLONIZING QUEER TIME: A CRITIQUE OF ANACHRONISM IN LATIN@ WRITINGS
}

\author{
Eliana de Souza Ávila* \\ Universidade Federal de Santa Catarina \\ Florianópolis, Santa Catarina, BR
}

\begin{abstract}
While the term Latin@ is untraceable to any coherent referent in terms of geographical or epistemic origin (Rodríguez 2014), still it denotes a very stable referent when it comes to geographical destination - the USA being the central migratory destiny shaped by and shaping identity shifts and epistemic positions variously associated with Latin America. As much as this narrative determinacy is the effect of global power asymmetries, it also tends to naturalize them by couching migration in evolutionist terms that anachronize struggles against displacement, deterritorialization, and dispossession. The field of Latin@ literature and criticism therefore becomes an effective locus from which the ongoing historical conflicts elided by those narratives can be creatively recalled and reconfigured. This article reflects on the temporal borderlands as a critical paradigm for reconfiguring narratives of straight temporality within Latin@ texts.
\end{abstract}

Keywords: Latin@ Studies; Anachronism; Racialization; Temporal Borderlands; Decolonization

Being grounded is not necessarily about being fixed; being mobile is not necessarily about being detached. ... What forces entrench migration, or propel staying 'at home'? Sara Ahmed et al., Uprootings/Regroundings

If identity is always a temporal drag, constituted and haunted by the failed love-project that precedes it, perhaps the shared culture-making projects we call "movements" might do well to feel the tug backwards as a potentially transformative part of movement itself. Elizabeth Freeman, "Packing History, Count(er)ing Generations"

[W] hen [something] proclaims itself invisible ..., that is when it most urgently demands an other, different

vision. José Quiroga, Tropics of Desire

\section{Introduction: Straight Temporality as Anachronism}

I highlight the epigraphs above because together they help to conceptualize the neologism Latin@ in ways that may counter the normative reduction of U.S. history to "a succession of flows of immigrants who, after being discriminated against, achieve the American dream" (Laó-Montes 131). Migration to Western spaces protected by global power tends to be understood as a natural temporal shift from the past to the present, from an anachronic to a postmodern temporality, whereas counterflux migration often gets framed as a backward move in global time. ${ }^{1}$ Along this straight temporality, complex migration processes undertaken by those led by necessity to search for social-economic improvement across borders tend to be mapped reductively on a timeline evolving from repression to freedom, ignoring

\footnotetext{
* Professor of English-Language Literatures at Universidade Federal de Santa Catarina in Florianópolis, Santa Catarina, Brazil. This article reflects part of her work as a visiting researcher in the Department of Latin American and Latino Studies and the Chicano Latino Research Center at the University of California at Santa Cruz, from August 2015 to July 2016, under a research grant generously awarded by CAPES, the Brazilian federal agency for improving higher education. Her email address is elavila.ufsc@gmail.com
} 
the specific contexts experienced by those whose lives increasingly clash with such linear expectations ${ }^{2}$ These narratives often become reduced to

oversimplified dynamics that re-inscribe dominant nationalist myths of the United States as a land of freedom and democracy and erase the struggle, suffering, and resistance experienced by subordinated groups... [Migrants'] subjectivities and histories become represented within colonialist, racist understandings of culture and identity. (Luibhéid xxv).

Against such reductions, Latin@ philosopher María Lugones has argued consistently that any project of decolonization requires decolonizing the racialized ways in which gender and sexuality constitute the central dichotomy between human and non-human ("Toward" 742) within the colonial/modern system within which, from the colonial period on, "the global population was differentiated into inferior and superior, irrational and rational, primitive and civilized, traditional and modern" ("Coloniality" 2). That these abject/normal dichotomies rely on a temporal boundary, or borderline, allows the racializing and gender formations they perpetuate to remain invisible under the anachronism that naturalizes them. Anachronism thus operates as an effective device interlocking the various constitutive hierarchies perpetuating what Quijano terms the coloniality of power: a division of the population of the planet along lines of race (2000b; 2001/2002); in Lugones's crucial revision, this is a cultural technology that hides the intersection of both race and gender in the subjugation of decolonial knowledges $(2007 ; 2008){ }^{3}$

The decolonial critique of temporality, according to Walter Mignolo, "emerged at the very foundation of [the colonial/modern divide], as its counterpoint" ("Manifesto" 46). ${ }^{4}$ In postcolonial thought, as Homi Bhabha pointed out in 1991, the problem of temporality "is often overlooked in more 'spatial' traditions of some aspects of postmodern theory" (170). ${ }^{5}$ Converging with Bhabha's view, Fredric Jameson clarifies in "The End of Temporality" that what has been called space is always already time, so that space still "risks becoming a misnomer" (706). Likewise, groundbreaking queer theories have been animated by questions of time, temporality, and futurity. ${ }^{6}$ In fact, the so-called "queer turn to temporality" is best understood as the recent realization or visibilization of temporality's central relevance in queer thought, considering that "temporality has inflected queer theory from the outset" (Freeman, Time Binds, xii). As Sam McBean points out,

[S]uch 'turn' rhetoric not only potentially obscures histories of concerns with time in queer theory, but also, in its apparent inauguration of a new field, makes it difficult to consider links between queer theory and histories of postcolonial, critical race, and feminist work. (11)

More accurately, then, this "turn" names the emergence, recognition, and consolidation of the epistemic impact of queer as a heterogeneous perspective, irreducible to an identity, that may contribute to transforming conceptions of history, futurity, and present reality itself.?

As an ideology of cultural effacement and a tool of epistemic violence, anachronism is only effective when naturalized by the binary narrative of straight time at the root of the colonial/modern temporal divide. Latin@ queer theorist José Esteban Muñoz refers to straight time as "a self-naturalizing temporality [the] 'presentness' [of which] needs to be phenomenologically questioned" (25). However, anachronism remains dominant in the temporal coding of queer sexuality.

\section{Insidious Anachronism in Queer Temporality}

As Jasbir Puar and others have argued, queer temporality has been coopted to reconfigure the colonial/modern divide; upscaled and institutionalized, what was once a signifier of disorderly nature and promiscuous behavior is now becoming a token of the so-called free west. ${ }^{8}$ In other words, the perceived threat of racialized others has been newly domesticated by a normative queer discourse anachronizing the others of the West, so that the nonwest, so far primitivized as being too queer, as we have seen above, has now been resignified as being not queer enough. Juxtaposed, 
the figures of both the queer and the migrant, despite - or because of - their power as emblems of bodily mobility and fluidity across borders of gender and nation, have increasingly become tokenized as figures of transcendence, mobility, and freedom, while reinstalling material and symbolic stagnation on the racialized sites of immobility. ${ }^{9}$

Against this neocolonial move, Latin@ scholarship has been scrutinizing the "discourse of the 'savage, unenlightened' third world versus the 'liberal and tolerant' first world" (Rodríguez, Queer Latinidad, 102) while also exposing the revalidation of what Jorge Ignacio Cortiñas refers to as the "regurgitation of neo-colonial narratives of the barbarity of the south" (qtd. in Rodríguez 111-112). These are coalitional critiques of queer discourses forging a "liberated West" still on the backs of those who live on what Lugones calls the "dark side" of colonial/modern temporality ("Heterosexualism"). As Jin Haritaworn, Tamsila Tauqir, and Esra Erdem argue in a related coalitional context, " $[\mathrm{t}]$ he amnesia at the basis of the sudden assertion of a [eurocentric] 'tradition' of anti-homophobic and antisexist 'core values' is less a reflection of progressive gender relations than of regressive race relations" (72).

Whether the meanings of Latin@ literature and criticism confirm or disturb this racializing timeline, they necessarily circulate within, across, or in excess of its norms. Straight temporality is expected to be naturally incorporated in any (not only straight) migrant text crossing a geotemporal border, so that the anachronic subject's newly granted access to mobility personifies and embodies an inherent shift from a recalcitrant pre-modern condition of lack (read: disability) to a triumphal post-modern temporality (read: ability). Against this racializing deployment of homophobia as a foil for the temporal production of a more civilized and free western subject, Latin@writer Daisy Hernández counters the narrative of personal and sexual freedom as a prerogative of the North: ${ }^{10}$

I think there's a perception that Latino families are more homophobic than other families. That wasn't my experience. There was such a range of reactions in my family. Of course there's an auntie who stopped speaking to me, but there's another auntie that was supporting me as I was going through a bad breakup, and there was an auntie who was in denial. And I think that kind of experience is really common in a lot of families-a variation of acceptance, denial, outcast. ${ }^{11}$

It is against this backdrop of anachronism in northbound narratives of queer liberation that the nomenclature Latin@ strategically appropriates queerness - or, more accurately, appropriates queerness so as to mark the insertion or latinidad within the advanced temporality of the west. Only apparently rather than structurally transformed, straight time is disturbed only to the extent that Latin@ flaunts the unacknowledged contemporaneity of its anachronized constituencies. This disturbance nonetheless provides a snapshot of the dominant parameter of temporality against which the renewed invisibility of racialized (read: anachronized) subjects and cultural epistemes must be named. In what follows, I will consider the significance of the temporal borderlands, drawn from Gloria Anzaldúa's writings (1987), as a de-anachronizing parameter for reading Latin@ criticism and literature.

In Anzaldúa's influential conception, each borderline is an "unnatural boundary" (3) which becomes denaturalized as it expands into proliferating borderlands through the creative power of liminality, shattering dichotomies as they travel between worlds of conflicting yet relational and transformative meanings. Anzaldúa's metaphor of the borderlands, though most often understood as a primarily spatial liminality, is also always already temporal. It is "created by the emotional residue of an unnatural boundary . . . a constant state of transition" experienced by "Los atravesados ... those who cross over, pass over, or go through the confines of the 'normal"' (3). From the perspective of the temporal borderlands in Latin@ texts, the confines of the normal, which render invisible los atravesados, are those of anachronism even when, and perhaps especially when, Latin@ texts reinvest in colonial/modern narratives of "entrance into contemporaneity". What inter-relational meanings emerge when we can no longer dismiss the colonial wound by reducing it to an anachronic, obsolete reality 
under the imperial rhetoric of contemporaneity as a prerogative of the north?

\section{Still, Anachronism}

Notice that in imperial rhetoric, as the previous statement makes clear, con-temporary, instead of meaning coeval time, has been reduced to monocentric or concentric time - a slippage that, in either case, performs contemporaneity as a prerogative of the (North-defined) West. ${ }^{12}$ Some instances of criticism on Latin@ literature give a typical account of this view.

For example, although Rosa Linda Fregoso does counter anachronism when she refers to Julia Alvarez's In the Time of the Butterflies as "a novel that crosses the border into the geographic space and history of the Dominican Republic and brings subjugated knowledges of women's history and struggle into the consciousness of mainstream readers," epistemic coevalness across borders does not seem to hold once she characterizes the author writing from the borderlands as herself "a bridge between the past and the present, Spanish and English, and, most significantly, between Dominican social history and contemporary English-speaking readers" (13). While the past in this sentence can be understood as the place lost in migration, and in this sense it cannot be conflated with a temporal identity of the place itself, it also performs ambivalence as such conflation does tend to occur in the context of the parallel dichotomies past/present, Spanish/English, and, most significantly, Dominican social history/contemporary Englishspeaking readers. In such accounts, the Latin@ writer's place of origin becomes reduced to a supposedly belated geopolitical locus. Even the borderlands, the metaphor claiming a "same territory" (Anzaldúa "Preface") and, implicitly, a same time, seem reduced to a bridge for a trajectory that culminates in a temporal, linguistic, and epistemological shift from past to present, with a monolinguistically-defined U.S. as its telos.

On the other hand, Fregoso also underscores Hispanic Caribbean women's ongoing resistance alongside the Latin@ novel's refusal to anachronize Latin American struggles as expected in the assimilationist pull of eurocentrism for Latin@ representations to literally leave Latin America behind in time. Foregrounding this coalitional feminist project in Alvarez's novel, Fregoso calls attention to how it conveys

\begin{abstract}
the contributions by women that are so often hidden from official state histories or accounts of sociopolitical movements for national independence, liberation, and decolonization. ... [T] he novel refuses to construct Latin American women as only victims of male oppression or objects of patriarchy. Although, in the end, the Mirabal sisters pay the ultimate price for their resistance, the novel recuperates the history of Latin American women's activism, the fact that Third World women resist despite huge penalties and refuse to give up in the face of harshly oppressive conditions. $(9 ; 12)$
\end{abstract}

Fregoso's reading of Alvarez's novel here refuses the narrative of straight temporality that naturalizes the denial and invisibilization of Latin American struggles for freedom and justice - as when the Latino critic Ilan Stavans portrays Alvarez's novel as "a wonderful examination of ... how it feels to come from $a$ society where justice and freedom are unwelcome" (63, my emphasis). This generalized characterization implies an essentialist predisposition for injustice and repression in Dominican society while assuming as progressive, by contrast, the U.S. society whose government funded the Trujillo regime to begin with (and one can also hear echoes of the colonial trope of laziness as the foil for the willful or self-reliant subject of the North). ${ }^{13}$ Such frequently expressed charges of endemic injustice reproduce straight temporality within Latin@ criticism while ignoring that violence continues to be reiterated by the same geopolitical hierarchy that renews itself invisibly under such ahistoricist narratives of the colonial/modern divide. Again, the characterization of a lacking sensibility for freedom and justice in the South with no reference to the relational historical contexts pervading Alvarez's novel reinstalls the trope of the uncivilized savage, erasing centuries of struggles for freedom and justice to imply that violence is merely a collective essence rather than a symptom of unevenly-structured historical relations. ${ }^{14}$ 
In this civilizational discourse, the non-migrant within Latin American societies becomes a foil for Latin@mobility, so that the decolonial rejection of anachronism is dismissed. The migrant is figured reductively as a receptor of the North's ability to welcome the realm of justice and freedom as if by geotemporal osmosis rather than by the hard work of unearthing the ongoing asymmetrical historical relations between cultures in coeval time. Such a discourse of evolutionary transition from a society marked as essentially disabled (read: temporally belated) to a newly-abled subject position within the North must elide the interlocking geocultural hierarchies of gender, class, race, sexuality, and ableism.

Further reiterating the gendered, heteronormative, and ableist trope of passivity, Stavans singles out the Mirabal sisters' political struggle for their "attack against phallocentrism as an accepted way of life in Hispanic societies" (62, my emphasis). Ironically, here phallocentrism is reinstalled at the very site of the geopolitical reproduction of the active Anglo over the passive Hispanic, attesting to the fact that not only their corresponding spaces but also the hierarchical relations between them are re-gendered and re-sexualized under phallocentrism in both straight and queer sexual connotations in the discourse of passivity. ${ }^{15}$ Crucially, this narrative of spatiotemporal exceptionalism evades the long history throughout which the U.S. government has been allowed to architect, fund, and further support a long series of dictatorships, tortures, genocides, and both overt and covert political coups overthrowing democratically-elected governments in Latin America - often precisely at moments of internal political and economic recovery. ${ }^{16}$ We must ask ourselves why these supporting actions are not themselves characterized as backward, and whether they are not protected by the discursive temporal framework of the colonial/ modern divide.

I hope to have sufficiently portrayed with these examples how the dominant parameters of straight time, or our epistemic unfamiliarity with the queer time of decolonization, reproduces colonial discourses in ways that tend to be unnoticed even within Latin@ criticism. The temporal borderlines inherited from colonial distancing techniques are updated and normalized within even the most groundbreaking critical discourses of geographical and identitarian mobility, leading them to strengthen the epistemic annihilation occurring at the root of assimilation processes. Even when assimilation is not so disciplined, such normalized temporal paradigms tend to remain illegible and thus in full force. Nelson Maldonado-Torres captures the problem of reading and writing under this regime of epistemic violence or illegibility as follows:

When the racialized subject writes and questions the premises of what is considered to be the "normal" world, she is hardly understood. ... There is simply a difference between the "normal" way of looking at the world (a normality which presupposes the questioning of the humanity of some subjects) and the perspective of someone who defies such normality. When the damnés write their claims they can hardly be understood by the "normal" world or translated into its way of understanding, quite simply because they demand another world and the emergence of different forms of life. Their writing is a means of creating them. ("Time of History" 8)

Indeed, scholars of decolonization have argued that the perpetuation of the coloniality of power, which ensures the modern/colonial split, operates at the epistemic level rather than only in the political and economic spheres. ${ }^{17}$ Historically embedded in the salvationist narrative of transitioning from immobility to freedom, Latin@ texts tend to be legitimized and celebrated only as they anachronize a supposedly past subjectivity within migrant writing itself. While violent power relations trigger both voluntary and forced migrations on a global scale, the narratives they produce often tend to protect the assimilating migrant's voice against the dehumanizing characterization of backwardness, reinstalling anachronistic mappings of contemporary existence and resistance. In what follows, I want to consider some instances in which, by contrast, straight time and its racializing implications are effectively challenged by the temporal borderlands in Latin@writings. 


\section{Condemned, or Made Invisible in Coeval Time}

Daisy Hernández's 2014 memoir A Cup of Water Under My Bed begins by making explicit the Latin@ author's writerly challenge: "I needed to see on paper the women and the father I had loved and resisted and betrayed, and to write them without the mancha of a white man who thought our lives and our stories should be bulldozed" (1, original emphases). This challenge appears as she exposes the term used against her family's world: "Condemned," further highlighted as the title of the introductory chapter. As she introduces her memoir, she explains that this is the term used by the town official who came to examine her family's house when she was a child. Asked to translate the official's words by her Spanish-speaking mother, the child downplays the violence they convey, and later in life realizes that she had not been able to translate the word because its epistemic meaning was non-existent in her family's way of understanding the world. Hernández explains, "I didn't have a word in our language that would say, "this photograph on the wall, this pot of black beans, this radio we listen to each day, these stories you tell us - he's saying none of this matters. It should be not only thrown away but bulldozed" (1). Yet, this impossible translation of the white-dominant world's attitude to the world and language of her family members has the effect of a betrayal, a lack of epistemic resistance, which her writing aims to revise.

Hernández's use of the word "betrayal" recalls a similar challenge, one articulated twenty years earlier by Cherríe Moraga. In her essay "Art in América, con Acento" (2003 [1994]), Moraga also refers to "betrayal" when she states that what she still seeks in "the woman writing in [her] that is worth her salt" is a writing "that dares to expose that very human weakness where we betray ourselves, our loved ones, even our own revolution" (160, my emphasis). To interpret this betrayal as evincing a purist ideology that cannot embrace the heterogeneous cultural perspectives epitomized by the migratory experience would be quite mistaken, for Moraga is referring to betrayal precisely as the homogenization of America: the theater I seek is a theater of healing, one that not only touches on the source of the wound but inspires its participants to act in the material world; to penetrate barriers of race, class, sexuality, geography; to refuse to identify with the 'we' of this America sin acento (...) (160, my emphasis).

Explicitly, then, the purist ideology Moraga refuses is an unaccented understanding of America, one that suppresses the spatiotemporal borderlands under the narrative of a melting pot incorporating others as long as they leave out - leave "behind" - their epistemic differences written off as obsolete. This coding of backwardness is itself a technology of epistemic violence: the power to delegitimize alternative perceptions and knowledges by producing them as anachronic and therefore unthinkable. Temporality plays a leading role in epistemic violence, since it naturalizes exclusion as a consequence of time itself rather than of racism or any other technology of hierarchization that has come under ethical scrutiny.

Moraga's criticism of the unaccented understanding of America is clearly an assertion of epistemic coevalness in the spatiotemporal borderlands, in a context in which perspectives from the South are rendered anachronic so as to maintain the temporal fortress which anchors the narrative of the North as liberationist telos. To engage the temporal borderlands exceeding straight time is not to transcend the borderlines of dominant temporality, or to deny such dominance and most of the world population's lived experience of being anachronized; it is, rather, to occupy that structure and insert it, by selfimplication rather than by opposition, in a relational, translocal, coeval temporality "deliberately confusing the boundaries of the local in an effort to capture the increasingly complicated nature of spatial processes and identities, ... viewing such processes and identities as place-based rather than exclusively mobile, uprooted or 'travelling"' (Oakes \& Schein 20).18 If the temporal borderlands are translocal, in that they "foreground multiplying forms of mobility without losing sight of the importance of localities in peoples' lives" (1), they are also transtemporal, foregrounding the asymmetrical relations against which queer temporality is felt and made significant as epistemic coevalness. 
Like Moraga, Hernández emphasizes the proliferation of epistemic borderlands when she writes that " $[t]$ here is no one of anything. There are many languages, many kinds of Spanish and English, of brown women and borders that do not shift beneath our feet but simply grow with every step we take" (19). These are proliferating sites of conflict where new knowledges emerge from closely related perspectives (Anzaldúa 1987), undermining anachronism as an elision of ongoing conflicting perspectives of history. It is from this perspective that the evolutionist narrative naturalizing geotemporal hierarchies falls apart in Hernández's memoir, and the trope of forward mobility from the repression associated with Colombia to the contemporary freedom associated with the U.S. is even mocked:

... I see myself in my social studies textbook. I am the Statue of Liberty, welcoming my mother to the land of the free, of the saved.

The textbooks carry pictures of women and men arriving at Ellis Island. The women in the photographs appear stoic, with obligatory bleak faces and thick eyebrows, their lips as thin as my mother's, and the caption begins: "They came..."

\section{What comes next varies.}

They came looking, they came searching, they came hoping - the verbs always more lively and ambitious than the women in the pictures, whose faces speak another refrain: "What the hell are you looking at?" (28)

By articulating this refrain, Hernández underscores the migrant women's reversal of the neocolonial gaze imprinted in the captions. Now occupying the position of the spectator interpellated by the women of color in the pictures, she resists her own complicity with the pervasiveness of coloniality's distancing techniques. This is a critical revision, therefore, of the developmental narrative she herself is expected both to assume, as an elementary school student, and to provide, as a successful writer.

To challenge the assumption of an easy continuum from a traditional to an advanced culture is not to deny the struggle for access to sites of hegemonic power, but to insist instead that "nothing happens in isolation" (1). This is the claim that makes Hernández's translocal narrative one of hearing and recalling the interconnectedness between what takes place quietly in the U.S. and its torturing resonances in Colombia within coeval time:

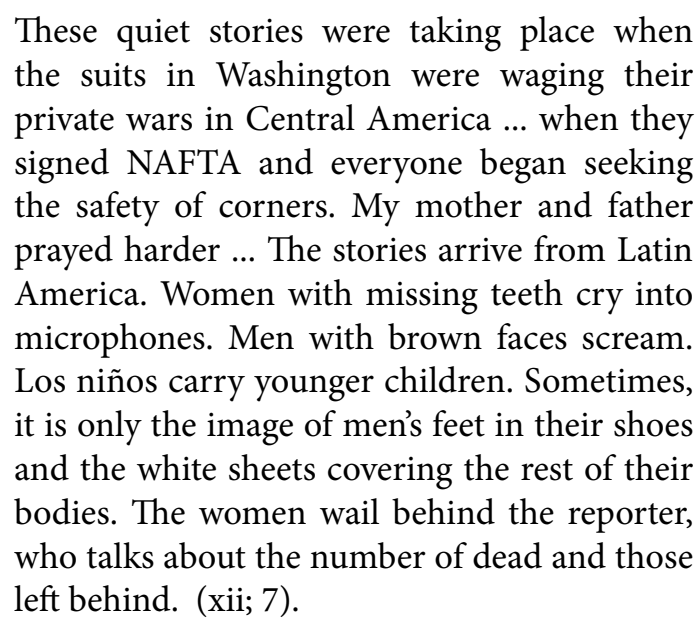

In this narrative, we cannot hear that they are "left behind" in such a way as to ignore the global relations in which straight time remains unquestioned. Thus significantly undercutting the evolutionist myth of migration to the U.S. as a movement from repression to freedom, Hernández portrays the "private wars in Central America" within the context of the signing of NAFTA, and further calls attention to elided geopolitical interconnectedness by following her mention of that signing with the phrase "and everyone began seeking the safety of corners" (1). Notice that this perspective undermines the depoliticizing narrative reproduced even within Latin@ criticism which relegates to the past century the concern of Latin@ texts with "naming or locating themselves within a geopolitical, ethnic, psychological, or spiritual borderland, as tended to occur in Chicana lesbian texts of the 1980s and 1990s" (Cuevas $\$ 12$ ). Instead of anachronizing the borderlands by covering up these broad contexts of epistemic annihilation, Hernández engages the intimate causality between imperial policies and migrant displacement, calling attention to the colonial wound where the mapping of the borders of space and time is most painfully felt. These accented writings are productively 
affected by the temporal borderlands, emerging as a consciousness of relational temporality for the production of a "meta-narrative of an interconnected history" which may "theorize the relations between local issues as relations between parts to a whole" (Alcoff 65).

Rather than denying the dominance of the nationstate's boundaries over lived spaces, Moraga and Hernández reject its primacy over what the former sees as the "land sin fronteras (...) within [the U.S.] nation" (“Queer Aztlán” 54). Moraga’s concept of Queer Aztlán, an imagined - and actively imagining - nation refusing the masculinist and heteronormative exclusionary politics of the Chicano movement, names a homeland open to "all its people, including its jotería".19 Rather than a project of mere inclusion, which would amount to unchanging assimilation under stable structures of power, this is a project of epistemic transformation:

[We] do not merely seek inclusion in the Chicano nation; we seek a nation strong enough to embrace a full range of racial diversities, human sexualities, and expressions of gender. ... [This is] an internal nation whose existence defies borders of language, geography, race . . . Increasingly, the struggles on this planet are not for 'nation-states', but for nations of people, bound together by spirit, land, language, history, and blood. $(164 ; 54 ; 169)$.

Within such struggles, both Moraga and Hernández write the complexity of nations sin fronteras where spatial and temporal borderlands proliferate through the shifting of epistemic geographies, even when their refusal to bulldoze el otro lado is reductively coded as "backward" on the map of straight time. By inscribing the temporal borderlands, their complicitous critique disallows any version of advanced temporality at the expense of re-anachronizing those coded as immobile in space and time. As Latin@ literature unsettles the borderlines between coeval histories, it brings into relational view the differential epistemic positions obliterated by straight temporality. From this perspective, the decolonial power of the expansive field of Latin@ literature, theorization, and criticism resides in its demystification of the master narrative that reduces the temporal borderlands to a denial - an idealized transcendence - of contemporary forms of anachronism.

\section{Acknowledgment}

I am very thankful to Laura Lomas (Rutgers University) for introducing me to Daisy Hernández's memoir, and for generously reading and commenting on previous drafts of this and other papers in which I have attempted to elaborate on the temporal dimension of Anzaldúa's conception of the borderlands.

\section{Notes}

1. My references to the "West" follow Walter Mignolo's terms, in his critique of the Rooseveltean transformation of the "Western Hemisphere" into the "North Atlantic" which, while dismissing Latin America from the so-called West, "also creates the conditions for the emergence of forces that remain hidden in the Creole (Latin and Anglo) ... rearticulation of Amerindian and Afro-American forces fed by the growing migrations and techno-globalism" $(2001,51)$.

2. I have developed this argument in the context of Edwidge Danticat's revisional historiography of genocide through genre trouble in The Farming of Bones (Ávila 2014a); and in the context of Chican@ cyber-art countering neocolonial anachronism (Ávila 2014b).

3. On the colonial/modern divide, see also Fabian 1983; Quijano 2000a; and Lugones 2007 and 2008, among others.

4. Briefly, Mignolo distinguishes decolonial from postcolonial perspectives thus: "the genealogy of these are located in French post-structuralism more than in the dense history of planetary decolonial thinking" ("Manifesto", 46).

5. The reference to spatial traditions of postmodern theory most often recalls the critical reception and legacy of such influential texts as Harvey 1990 and Jameson 1991.

6. See, especially, Sedgwick 1993; Edelman 2004; Freeman 2000, 2005, and 2010; Muñoz 2009; and Kafer 2013.

7. The episteme is generally defined as the paradigm of knowledge prevailing in each specific historical context, but in Michel Foucault's conception it is also that which confers legitimacy to some cultural perspectives, values, and perceptions over others, thus operating as a regulatory power limiting, defining, and stabilizing 
what is legible and thinkable - and, by implication, what has the power to threaten such stability. In this light, the episteme has the simultaneous effect of legitimating some normative discourses as true, and of annihilating others which Foucault therefore terms "subjugated knowledges" (1980, 81). However, far from being a deterministic master narrative, the episteme restricts and conditions discourse while at the same activating its epistemological instability; in other words, it potentializes the impact of new epistemes within processes of emerging legitimation and legibility (1966). On the "epistemic decolonial turn," see Grosfoguel 2007 as well as Mignolo 2007, 2009, and 2011.

8. See Puar 2005 and 2007; Agathangelou et al. 2008; Haritaworn et al. 2008; Schulman 2012; Ritchie 2014; Jackman and Upadhyay 2014; Puar and Mikdashi 2015; and Haritaworn 2015, among others.

9. On the inequation of queerness and migration with a necessarily transgressive mode of existence, see Ahmed 2000; Ahmed et al. 2003; Wesling 2008, and others. Following Martin 1995 and Ong 1999, Jack Halberstam also argues against the neoliberal transmutation of capitalism emerging in the "seemingly radical ethic of [trans] gender flexibility" $(2005,19)$.

10. In the context of Latin@ studies, I refer to the North/ South dichotomy as a real effect, or a lived reality, of the coloniality of power. I thus follow Mignolo, who has written:

I refer to the South in the general sense that includes Central America and the Caribbean, 'south of Rio Grande' in the one sense; and the Caribbean that in spite of being English or French, has more in common with the South than with the North, that is, North America (U.S. and Canada). Briefly, the imperial/ colonial history is what is at stake rather than European or North American textbooks on geography. (Mignolo 2007, 14, fn 1)

On the relationship between North and West, see my second footnote, above.

11. Daisy Hernández interviewed by Ariana Vives for Bitchmedia.org. See https://bitchmedia.org/post/paralas-hijas-an-interview-with-author-daisy-hernandez

12. Briefly, it must be noted that heterogeneous time does not preclude straight time. On the West as Northdefined, see my footnote 1 .

13. On the U.S. support of the Trujillo regime, see, for example, Renda 2001 and Kaussen 2008.

14. I refer to the Franz Fanon's statement that "sociogenesis ... a question of sociodiagnostic" (1967 [1952], 11).

15. On the gendered relations of the global/local dichotomy, see Carla Freeman 2001.
16. See McSherry 2005; Grandin 2006; Kaussen 2008; Green 2010; Dávila 2013; and McPherson 2015, among others.

17. See, for example, Chatterjee 1986 and Mignolo 2011.

18. Translocality is a simultaneous understanding of both situatedness and connectedness with various locales, what Michael Burawoy calls "global connections between [local] sites" (29) that themselves play active roles in expanding epistemic knowledge and relationality.

19. Jotería is increasingly used to refer to queers of Latin@, Chican@, and Indigenous affiliation.

\section{References}

Agathangelou, Anna M., Daniel Bassichis, and Tamara L. Spira. "Intimate Investments: Homonormativity, Global Lockdown, and the Seductions of Empire". Radical History Review 100 (2008): 120-43.

Ahmed, Sara, Claudia Castañeda, Anne-Marie Fortier, and Mimi Sheller. "Introduction." In Uprootings/ Regroundings: Questions of Home and Migration. New York: Berg, 2003.

Strange Encounters: Embodied Others in PostColoniality. London and New York: Routledge, 2000.

Alcoff, Linda Martín. "Enrique Dussel's Transmodernism," Transmodernity: Journal of Peripheral Cultural Production in the Luso-Hispanic World, 1.3 (2012): 60-68.

Alvarez, Julia. In the Time of the Butterflies. New York: Plume, 1995.

Anzaldúa, Gloria. Borderlands / La frontera: The New Mestiza. San Francisco: Aunt Lute Books, 1987.

Ávila, Eliana. "Decolonizing Straight Temporality through Genre Trouble in Edwidge Danticat's The Farming of Bones". Ilha do Desterro 67, June-Dec 2014a. 21-36.

"Do High-Tech à Azteca: Descolonização cronoqueer na ciber-arte chicana”. Revista Estudos Feministas 23.1, Jan-Apr 2014b. 191-206.

Bhabha, Homi K. "Race, Time, and the Revision of Modernity." Postcolonial Criticism. Edited by Bart Moore-Gilbert, Gareth Stanton, Willy Maley. New York: Routledge, 2013 [1991]. 166-90.

Burawoy, Michael. "Introduction: Reaching for the Global." In Global Ethnography: Forces, Connections, and Imaginations in a Postmodern World. Edited by Michael Burawoy et al. Berkeley: University of California Press, 2000.

Chatterjee, Partha. Nationalist Thought and the Colonial World: A Derivative Discourse? London and Delhi: Oxford University Press, 1986. 
Cuevas, T. Jackie. "Imagining Queer Chican@s in the Post-Borderlands," Revue LISA/LISA e-journal. International Perspectives on the Transforming USA in the 21st Century. 11.2 (2013): online. Accessed 12 April 2016.

Dávila, Jerry. Dictatorship in South America. Malden and Oxford: Blackwell, 2013.

Dussel, Enrique. "World System and 'Trans'-Modernity. Trans. Alessandro Fornazzari. Nepantla: Views from South 3.2 (2002): 221-44.

Edelman, Lee. No Future: Queer Theory and the Death Drive. Durham: Duke University Press, 2004.

Fabian, Johannes. Time and the Other: How Anthropology Makes Its Object. New York: Columbia University Press, 1983.

Fanon, Franz. Black Skin, White Masks. Translated by Charles Lum Karkmann. New York: Grove, 1967 [1952].

. Les Damnés de la Terre. Paris: François Maspero, 1961. [Published in English as The Wretched of the Earth, trans. Constance Farrington (New York: Grove Press, 1965).]

Foucault, Michel. Power/Knowledge: Selected Interviews and Other Writings. New York: Pantheon, 1980.

Les mots et les choses. Paris: Gallimard, 1966.

Freeman, Carla. "Is Local : Global as Feminine : Masculine? Rethinking the Gender of Globalization." Signs: Journal of Women in Culture and Society 26.4 (2001): 1007-1037.

Freeman, Elizabeth. Time Binds: Queer Temporalities, Queer Histories. Durham: Duke University Press, 2010.

. "Time Binds, or, Erotohistoriography." Social Text 23.3-4 (Fall-Winter 2005): 57-68.

"Packing History, Count(er)ing Generations." New Literary History 31.4 (2000): 727-44.

Fregoso, Rosa Linda. "Julia Alvarez, In the Time of the Butterflies." Reading U.S. Latina Writers: Remapping American Literature. Edited by Alvina E. Quintana. New York and Palgrave Macmillan, 2003. 7-14.

Grandin, Greg. Empire's Workshop: Latin America, the United States, and the Rise of the New Imperialism. New York: Henry Holt \& Co., 2006.

Green, James Naylor. We Cannot Remain Silent: Opposition to the Brazilian Military Dictatorship in the United States. Durham: Duke University Press, 2010.

Grosfoguel, Ramón. "The Epistemic Decolonial Turn: Beyond Political-Economy Paradigms." Cultural Studies 21.2/3 (March/May 2007). 211-23.
Halberstam, Judith [Jack]. In a Queer Time and Place: Transgender Bodies, Subcultural Lives. New York and London: New York University Press, 2005.

Haritaworn, Jin. 2015. Queer Lovers and Hateful Others: Regenerating Violent Times and Places. London: Pluto Press.

Haritaworn, Jin, Tamsila Tauqir, and Esra Erdem. "Gay Imperialism: Gender and Sexuality Discourse in the 'War on Terror." Out of Place: Interrogating Silences in Queerness/Raciality. Edited by Adi Kuntsman and Esperanza Miyake. York: Raw Nerve Books, 2008. 71-95.

Harvey, David. The Condition of Postmodernity. Oxford: Basil Blackwell, 1990.

Hernández, Daisy. A Cup of Water Under My Bed. Boston: Beacon Press, 2014.

Jackman, Michael Connors, and Nishant Upadhyay. "Pinkwatching Israel, Whitewashing Canada: Queer (Settler) Politics and Indigenous Colonization in Canada." Women's Studies Quarterly 42.3-4 (Fall 2014): 195-210.

Jameson, Fredric. "The End of Temporality". Critical Inquiry 29.4 (2003): 695-718.

Postmodernism, or, The Cultural Logic of Late Capitalism. London and New York: Verso, 1991.

Kafer, Alison. Feminist, Queer, Crip. Bloomington: Indiana University Press, 2013.

Kaussen, Valerie. Migrant Revolutions: Haitian Literature, Globalization, and U.S. Imperialism. Lanham: Rowman \& Littleman, 2008.

Laó-Montes, Agustin. "Afro-Latinidades: Bridging Blackness and Latinidad." Technofuturos: Critical Interventions in Latina/o Studies. Edited by Nancy Raquel Mirabal and Agustin Laó-Montes. Lanham and Plymouth: Lexington, 2007. 117-140.

Lugones, María. "Toward a Decolonial Feminism." Hypatia 25.4 (Fall 2010): 742-759.

. "The Coloniality of Gender." Worlds \& Knowledges Otherwise (Spring 2008): 1-17.

"Heterosexualism and the Colonial/Modern Gender System." Hypatia 22.1 (Winter 2007): 186-209.

Luibhéid, Eithne. "Introduction: Queering Migration and Citizenship." Queer Migrations: Sexuality, U.S. Citizenship, and Border Crossings. Edited by Eithne Luibhéid and Lionel Cantú. Minneapolis: University of Minnesota Press, 2005. ix-xxxv.

Maldonado-Torres, Nelson. "On the Coloniality of Being: Contributions to the Development of a Concept." Globalization and the Decolonial Option. Edited by 
Walter Mignolo and Arturo Escobar. New York: Routledge, 2010. 94-125.

. "The Time of History, the Times of Gods, and the Damnés de la terre." Worlds \& Knowledges Otherwise (Spring 2006): 1-12.

Martin, Emily. Flexible Bodies. Boston: Beacon Press, 1995.

McBean, Sam. Feminism's Queer Temporalities. New York: Routledge, 2016.

McPherson, Alan. A Short History of U.S. Interventions in Latin America and the Caribbean. Hoboken: John Wiley \& Sons, 2015.

McSherry, J. Patrice. Predatory States: Operation Condor and Covert War in Latin America. Lanham and Boulder: Rowman \& Littlefield, 2005.

Mignolo, Walter. "Epistemic Disobedience and the Decolonial Option: A Manifesto." TransModernity: Journal of Peripheral Cultural Production of the LusoHispanic World (Fall 2011): 44-66.

"Epistemic Disobedience, Independent Thought and De-Colonial Freedom." Theory, Culture \& Society 26.7-8 (2009): 1-23.

"Epistemic Disobedience: The De-colonial Option and the Meaning of Identity in Politics." Gragoatá 22 (10. semestre 2007): 11-41.

"Coloniality at Large: The Western Hemisphere in the Colonial Horizon of Modernity." The New Centennial Review 1.2 (2001): 19-54.

Moraga, Cherríe. "Art in America, con Acento." Women Writing Resistance: Essays on Latin America and the Caribbean. Cambridge: South End Press, 2003 [1994]. 101-08.

"Queer Aztlán: The Reformation of the Chicano Tribe." The Last Generation: Prose and Poetry. Boston: South End Press, 1993. 148-49.

Muñoz, José Esteban. Cruising Utopia: The Then and There of Queer Futurity. New York and London: New York University Press, 2009.

Oakes, Tim, and Louisa Schein. "Translocal China: An Introduction.” In Translocal China: Linkages, Identities, and the Reimagining of Space. Edited by Tim Oakes and Louisa Schein. London: Routledge, 2006. 1-35.

Ong, Aihwa. Flexible Citizenship: The Cultural Logics of Transnationality. Durham: Duke University Press, 1999.

Puar, Jasbir K. Terrorist Assemblages: Homonationalism in Queer Times. Durham: Duke University Press, 2007.

“Queer Times, Queer Assemblages." Social Text

84-85, 23.3-4 (Fall-Winter 2005): 121-39.
Puar, Jasbir, and Maya Mikdashi. "Pinkwatching and Pinkwashing: Interpenetration and Its Discontents." Jadaliyya. Arab Studies Institute, 9 Aug. 2012. Web. 01 Dec. 2015.

Quijano, Anibal. “Colonialidad del poder, globalización y democracia. Revista de Ciencias Sociales de la Universidad Autónoma de Nuevo León, Año 4, 7-8 (Septiembre 2001-Abril 2002).

. "Coloniality of Power, Eurocentrism, and Latin America." Nepantla: Views from South 1.3 (2000a): 533-80.

"Colonialidade del Poder y Clasificacion Social." Festschrift for Immanuel Wallerstein. Special issue, Journal of World Systems Research 5.2 (Summer/Fall 2000b). 93-126.

Quiroga, José. Tropics of Desire: Interventions from Queer Latino America. New York: New York University Press, 2000.

Renda, Mary. Taking Haiti: Military Occupation and the Culture of U.S. Imperialism, 1915-1940. Chapel Hill and London: University of North Carolina Press, 2001.

Ritchie, Jason. "Pinkwashing, Homonationalism, and Israel-Palestine: The Conceits of Queer Theory and the Politics of the Ordinary." Antipode 47.3 (2014): 616-34.

Rodríguez, Juana Maria. "Latino, Latina, Latin@." Keywords for American Cultural Studies. Second Edition. Edited by Bruce Brugett and Glenn Hendler. New York: New York University Press, 2014. 146-49.

Queer Latinidad: Identity Practices, Discursive Spaces. New York: New York University Press, 2003.

Schulman, Sarah. Israel/Palestine and the Queer International. Durham: Duke University Press, 2012.

Sedgwick, Eve K. Tendencies. Durham, NC: Duke University Press, 1993.

Stavans, Ilan. The Essential Ilan Stavans. New York: Routledge, 2000.

Wesling, Meg. "Why Queer Diaspora?” Feminist Review 90 (2008), 30-47.

Recebido em: 07/07/2016 Aceito em: 16/12/2016 